\section{International Scientific Journal Theoretical \& Applied Science}

Mariya Kasimbaevna Sayakova doctor of juridical science, acting professor first vice-rector of Institute of Modern Information Technologies in Education of Kyrgyz Republic

\author{
Ailen Dokturbekovna Adambekova \\ doctor of juridical science \\ Senior Researcher of Academy of Ministry of \\ Interrior Affairs of Kyrgyz Republic
}

SECTION 32. Jurisprudence.

\title{
THE PROBLEM OF RELIGIOUS EXTREMISM OF WOMEN IN THE KYRGYZ REPUBLIC
}

\author{
Abstract: The article examines the criminological aspect of activating the participation of women in religious \\ extremist activities. \\ Key words: religious extremism, national security of the state, traditional Islam, religious policy, radical \\ organizations, focus groups. \\ Language: Russian \\ Citation: Sayakova MK, Adambekova AD (2018) THE PROBLEM OF RELIGIOUS EXTREMISM OF \\ WOMEN IN THE KYRGYZ REPUBLIC. ISJ Theoretical \& Applied Science, 03 (59): 218-222. \\ Soi: http://s-o-i.org/1.1/TAS-03-59-36 Doi: crossef https://dx.doi.org/10.15863/TAS.2018.03.59.36

\section{ПРОБЛЕМА РЕЛИГИОЗНОГО ЭКСТРЕМИЗМА ЖЕНЩИН В КЫРГЫЗСКОЙ РЕСПУБЛИКЕ} \\ Аннотация: В статье рассматривается криминологический аспект активизациии участия женщин в \\ религиозно-экстремистской деятельности. \\ Ключевые слова: религиозный экстремизм, национальная безопасность государства, традиционный \\ ислам, религиозная политика, радикальные организациии, фокус-группы.
}

\section{Introduction}

Говоря о новых тенденциях в качественном изменении структуры женской преступности, нельзя не отметить проблемы, связанные с участием кыргызстанских женщин в религиозноэкстремистской деятельности. Настораживает тенденция возрастания доли женщин в различного рода экстремистских организациях. До сего дня правоохранительные органы Кыргызской Республики задерживали только приверженцев запрещенной организации «Хизбут-тахрир» мужского пола, однако сегодня, наряду с наркотиками, проходят и женщины, которые активно пропагандируют радикальные идеи, создавая женские группы. Среди них имеется определенное количество женщин, являющихся родственницами тех мужчин, которые ранее были причастны к экстремистской или террористической деятельности. Анализ складывающейся обстановки в религиозной сфере показывает, что экстремистские организации активно продолжают свою деструктивную деятельность на территории стран Центральной Азии, в том числе в Кыргызской
Республике, в целях расширения своего присутствия, распространения экстремистской идеологии и привлечения новых членов из числа местного населения. Порядка 500 граждан Кыргызстана, включая 122 женщин, находятся в настоящее время на территории Сирии в рядах международных террористических организаций. Об этом сообщила генеральный прокурор Кыргызстана Индира Джолдубаева, выступая на 7-й региональной конференции Международной ассоциации прокуроров для государств Центральной и Восточной Европы и Центральной Азии в Сочи [7]. По данным Организации Объединенных Наций, за 5 лет число присоединившихся в ряды боевиков в Сирии и Ираке кыргызстанцев превысило 800, из них около 200 женщин [1].

\section{Materials and Methods}

Международные экстремистские организации проводят активную работу по вербовке молодых девушек, причем упор делается на девушек в возрасте от 16 до 20 лет в 
связи с тем, что в таком возрасте психика и ценности девушек являются не сформированными полностью и они легко поддаются чужому влиянию. Большинство их выехало под предлогом занятия коммерцией. По некоторым сведениям женщины ходят вместе с боевиками как их супруги, а после гибели мужа на войне по условиям шариата берут на себя обязательство исполнять обязанности жены следующему боевику. Конечно, не говоря об угрозе жизни, идти сознательно на такое унижение и терпеть равноценно полной потере разума.

Сейчас на учете органов внутренних дел находятся примерно две тысячи сторонников религиозного экстремизма. Если сказать об их возрасте, то мужчинам 30-35 лет, женщинам 1825 лет. Ясное дело, для молодежи, не сумевшей найти свое место в жизни и без разбора хватающейся за все, попасть в такой капкан очень легко. Имеется существенная разница между числом мужчин и числом женщин, сторонников религиозно-экстремистских организаций, состоящих на учете органов внутренних дел (92,2\% мужчин и 7,8\% женщин). Тем не менее, следует отметить, что женщины наряду с мужчинами активно участвуют в экстремистской деятельности, создают свои группы. Возрастные данные лиц, причастных к деятельности религиозно-экстремистских организаций по республике выглядят таким образом: 19-24 - 20\%; 25-29 - 30,5\%; 30-39 $35,3 \%$; 40-49 - 10,2\%; 50 лет и старше - 2,2\%. Детальный анализ лиц, состоявшихся в учете органов внутренних дел, а также осужденных, показали, что $8,2 \%$ сторонников экстремистских организаций имели высшее образование; $12,3 \%-$ среднее-специальное; $83,7 \% \quad$ образование. Из общего количества выявленных приверженцев экстремистских организаций 70\% составляют безработные. Прежде всего, следует отметить, что за 26-летний период самостоятельного существования суверенного Кыргызстана, возможности для проникновения на его территорию чуждых для данного региона идеологий, не имеющих отношения к исторически сложившимся здесь традициям умеренного мусульманского вероучения, стали намного шире. Об этом зримо свидетельствует колоссально возросшее количество мечетей, построенных на деньги спонсоров из арабских стран. Бесконтрольный резкий рост количества новых мечетей в отдаленных селах Кыргызстана в какой-то степени способствует религиозной радикализации местного сообщества. По данным Духовного управления мусульман, в Кыргызстане зарегистрировано 2 тыс. 678 мечети, 600 из них были построены за последние 5 лет. По информации же Государственной комиссии по делам религий, цифры несколько иные: действуют в республике 2 тыс. 778 мечетей, но при этом регистрацию прошли лишь 1 тыс. 922. На момент развала СССР на территории Кыргызстана официально действовали 39 мечетей [2] и 81 исламское учебное заведение. Также зарегистрировано 68 мусульманских центров, фондов и объединений, занимающихся образовательной, просветительской, благотворительной деятельностью и строительством культовых объектов. По областям и городам количество мечетей представлено следующим образом: Ошская область - 822, Жалал-Абадская область — 632, Чуйская область - 384, Баткенская область - 362, Иссык-Кульская область - 180, Нарынская область - 150, Таласская область 133, город. Ош - 58, город. Бишкек - 57. Из 2778 мечетей 429 еще не прошли регистрацию [3].

Это угрожает тем, что может произойти раскол религиозного сообщества в отдаленных селах. Имеются факты, когда мечети строятся чуть ли не на каждой улице, при этом в большинстве из них без элементарных благ цивилизации. И ни в одном из них не созданы условия для посещения женщин. В городе Баткене при муфтияте функционируют всего несколько медресе, и они охватывают лишь малую часть населения. В остальных медресе содержание проповеднических мероприятий со стороны ДУМК контролируется не в полной мере. К сожалению, отмечены такие случаи, когда женщины с неизвестной программой обучения собирают группы молодых девушек и женщин и проводят обучение на дому (худжры). При рейде правоохранительными органами выяснилось, что у самих наставниц нет должного религиозного образования. По мнению правоохранительных органов, участились случаи, когда многие старшеклассницы после 9-го класса переходят на учебу в один из подобных медресе и худжры. Как они объяснили, первые шаги религиозного просвещения девочки получают именно в подобных кружках. Есть вероятность, что в таких кружках радикальные течения внедряют свои идеи в несформировавшееся мировоззрение подростка. Молодых людей с неправильным пониманием религии можно отправить куда угодно «во имя Аллаха». Следует отдельно отметить, что качественный состав имамов в отдаленных селах оставляет желать лучшего. Многие из них ограничены выполнением лишь нескольких обязательных обрядов (такие как, чтение намаза, жаназа, совершения обряда нике и т.д.), они не в состоянии донести истинную суть религии из-за низкого уровня религиозной грамотности. Серьезной проблемой остается отсутствие 
системы религиозного образования и уровень знаний имамов мечетей, $72 \%$ имамов не имеют религиозного образования, общее среднее образование имеют $25 \%$, а высшее религиозное имеют лишь 5\% имамов. Ситуация усугубляется неконтролируемым и бессистемным подходом к образовательному процессу в религиозной сфере. При проведении аттестации 92 процента руководителей религиозных учебных заведений были не допущены, так как не соответствовали требованиям, в частности, из-за отсутствия светского образования, из 1,3 тысячи имамов 800 прошли аттестацию, остальные не соответствовали требованиям [4]. Еще хуже обстоят дела с директорами религиозных образовательных учреждений - 66 из 71-го вообще не были допущены к аттестации.

И как следствие, из-за низкой религиозной грамотности граждане поддаются влиянию деструктивных, экстремистских организаций и выезжают в зоны боевых действий.

Следует выделить несколько направлений сотрудничества по данной проблеме. Так, если религиозное НПО и медики начали совместную работу по основам укрепления здоровья, оказанию первой медицинской помощи, то областные казияты совместно с правоохранительными органами начали проводить обучающие мероприятия для школьников. Кроме того, сами сотрудники милиции проходят курс обучения по основам традиционного ислама в целях предотвращения религиозной радикализации. Представители женсовета отметили, что проводят совместно с имамами регулярные квартальные встречи по вопросам религии с женщинами-домохозяйками, школьницами старших классов. Представители местной государственной администрации по социальным вопросам рассказали, что активно участвуют в распространении и реализации государственной религиозной политики, ведут учет и регистрацию мечетей и медресе.

Участники предложили провести активные информационно-просветительские мероприятия через телевидение и радио, местные газеты, во время пятничных намазов в мечетях касательно идей традиционного ислама среди населения. Как заметил представитель религиозного НПО, пришло время проводить разьяснительную работу по поводу общечеловеческих, нравственно-моральных и семейных ценностей в исламе, предостерегающих от идей религиозного радикализма.

Не менее важным, как отметила религиозная женщина - участница ФГД, является гармонизация взаимоотношений между религиозными людьми и светским обществом, проявление терпимости, уважения взглядов, интересов и потребностей религиозных женщин со стороны светского общества.

Подводя итоги всех фокус-групповых дискуссий, следует отметить, что только совместными усилиями государства, религиозных организаций и гражданского общества можно добиться скоординированных и действенных решений по предотвращению религиозного радикализма среди женщин в местном сообществе, прийти к какому-либо консенсусу - в вопросах ношения хиджаба, ведь ежегодно в государственных школах возникают проблемы, связанные с ношением хиджаба ученицами, преподавателями и персоналом [6]. Эта тема становится предметом оживленных дискуссий, но в итоге никак не решается.

Современное кыргызстанское общество характеризуется наличием целого ряда факторов, усиливающих гендерное неравенство в стране, несмотря на то, что проводятся активные мероприятия со стороны государства, гражданского общества и ряда международных организаций.

Эмиссары, продвигающие, например, ваххабитские взгляды, проникали в страну достаточно свободно, прикрываясь культурнопросветительскими инициативами.

Одновременно с этим, в соответствии с тенденциями современного информационного прорыва, получили широкое распространение возможности пользования сетевыми электронными ресурсами, что фактически сделало неограниченными возможности вирусного распространения этих чуждых установок и призывов.

Ко всему указанному необходимо присовокупить хронические неурядицы страны, связанные с нереализованными в полной мере попытками достижения устойчивого и стабильного экономического и социальнополитического развития. Высокий уровень безработицы, отсутствие социальных лифтов для молодежи толкают в поисках выхода к тем, кто обещает некий альтернативный мир, коренным образом отличающийся от безысходной повседневности.

Что касается женщин, то их положение, особенно в отдаленных от столичного центра областях, значительно трансформировалось за прошедшие годы в направлении отката к прежним «домостроевским» временам, гендерной дискриминации и насилию. Фактическое бесправие в семьях, сопровождаемое их религиозным перерождением, также способствует тому, что - вслед за своими мужьями, сыновьями - женщины рекрутируются для выезда в страны и регионы, где осуществляется попытка утвердить некие новоявленные формы халифата. 
Зависимое положение женщины становится криминогенным фактором вовлечения ее в совершение преступлений экстремистской направленности. За последний период усилилось желание женщин к возрождению традиций и обычаев, к соблюдению предписаний шариата. Возвращается брачный выкуп и снижается минимальный возраст вступления в брак, родители спокойно выдают своих дочерей после окончания девятого класса, «чтобы поскорее избавиться от лишних хлопот и лишнего рта в семье» тем более, если подвернется подходящий мужчина, причем зрелого возраста, который берет ее в качестве второй или третьей жены. Многоженство перестало рассматриваться как противоправное деяние. Это опять таки заметно в южном регионе [5, с. 174-177]. Количество ранних браков, по данным Нацстаткомитета, почти в полтора раза больше в сельской местности и среди бедных слоев населения, а бедность сужает доступ к базовым потребностям, таким как образование, медицина, бедность, обостряет проблему выживания. Многие женщины не понимают различий между течениями. Они не способны на самостоятельный анализ, формулировку вопросов.

Брачный выкуп за невесту, ставит женщину в зависимое положение в семье. Формированию зависимой и безропотно подчиняющейся личности молодой женщины способствует процесс религиозного просвещения девочек, отказ от светского образования. Подчинению молодых женщин экстремистскому влиянию способствует и деятельность местных религиозных учебных заведений. Поэтому можно сказать, что зависимое поведение женщины является в некоторой степени основой вовлечения ее в совершение преступлений экстремистской направленности. Например, На юге Кыргызстана две женщины осуждены за наемническую деятельность в рядах террористической организации «Исламское государство». Об этом сообщает ВС КР. Гражданок КР Джалал-Абадский областной суд приговорил к семи годам лишения свободы. Вердикт первой инстанции остался в силе. Уточняется, что 55-летняя Мохирахон Акимжанова приговорена к шести годам лишения свободы с отбыванием в исправительной колонии. А 30-летняя Наргизахон Раимжонова получила семь лет [10]. Обе обвиняются по статьям «Наемничество», «Подделка, изготовление, сбыт или использование, приобретение, хранение, распространение, перевозка и пересылка экстремистских материалов, а также умышленное использование символики или атрибутики экстремистских организаций» УК КР.

\section{Conclusion}

То, что власти Кыргызстана стремятся к контролю и одновременно к консенсусу с конструктивными религиозными организациями, свидетельствует о стремлении наладить толерантный диалог с умеренными исламскими группами, возможности просветительских диспутов с ними и открытый контроль их деятельности со стороны компетентных органов. Ведь излишне жесткие карательные меры лишь загоняют их в подполье и способствуют их радикализации, общему росту напряженности в Кыргызстане, что в перспективе чревато непредсказуемыми последствиями [8]. Только совместными усилиями государства, религиозных организаций и гражданского общества можно добиться скоординированных и действенных решений по предотвращению религиозного радикализма среди женщин в местном сообществе. В связи с этим необходимы следующие меры.

1. Разработать целевые программы, направленные на оказание адресной поддержки религиозным женщинам из социально уязвимых групп населения, в особенности молодым женщинам, чтобы они могли реализовать свои экономические возможности (усилить доступ к таким базовым социальным услугам, как медицина, образование, социальная защита) [9].

2. Внедрить различные модели дошкольных образовательных учреждений для детей в местном сообществе для того, чтобы женщины в религиозных сообществах могли самореализоваться и трудоустроиться (ведомственные, частные, семейные).

3. Разработать механизмы предоставления профессионально-технического образования и дальнейшего трудоустройства женщин из группы риска на местном уровне - консультационные пункты (по созданию бизнес-цепочки, поиску заемных средств, лизингу, маркетингу, рекламе и пр.), бизнес-инкубаторы, ресурсные центры, тренинговые центры.

4. В вопросах относительно ношения платка и хиджаба в школах, университетах и других государственных учреждениях государственным органам и Духовному управлению мусульман необходимо найти компромиссное решение посредством диалога и совместных образовательных кампаний. Создать платформы для женщин, где будут условия для обсуждения религиозных проблем местного сообщества, в частности, проблем вовлечения женщин в религиозный радикализм.

5. Усилить сотрудничество между местными казыятами и образовательными учреждениями в вопросах формирования общечеловеческих нравственно-моральных и семейных ценностей, предостерегающих от идей религиозного 
радикализма. Проводить регулярные тренинги для имамов по предотвращению религиозного радикализма, в частности среди женщин, и популяризировать традиционные идеи ислама. Активизировать проведение информационнопросветительских кампаний в СМИ и в мечетях во время пятничных намазов по распространению идей традиционного ислама, по предотвращению идей религиозного радикализма среди различных групп населения: женщин, молодежи, учащихся и т.д.

6. Содействовать проведению проектной деятельности НПО, направленной на интеграцию женщин из маргинальных групп населения посредством предоставления консультативной, обучающей, просветительской и ресурсной помощи. Инициировать проекты, пропагандирующие вопросы гендерного равенства среди религиозных женщин на местном уровне с целью ограждения женщин от гендерно-религиозной дискриминации. Усилить партнерство между государственными органами, органами местного самоуправления, религиозными организациями, институтами гражданского общества по координации совместных действий по предотвращению религиозного радикализма среди женщин в местном сообществе.

\section{References:}

1. (2018)

Available: http://www.gezitter.org/society/67277_opros (Accessed: 10.03.2018).

2. (2018) Available: http://www.24.kg/ (Accessed: 10.03.2018).

3. (2018) Available: http://kg.akipress.org/news: (Accessed: 10.03.2018).

4. (2018) http://24.kg/obschestvo/28134/

Available: 10.03.2018)

(Accessed:

5. ZH.F. Moldokeeva, A.T. Asylbekova (2016) Gendernaya diskriminaciya kak faktor religioznoj radikalizacii zhenshchin na yuge Kyrgyzstana. Vestnik Kyrgyzsko-Rossijskogo Slavyanskogo universiteta. 2016, Tom 16 №10. - Bishkek. - p. 174-177.

6. V.G. Kryuchkov (2018) Problemy ehkstremizma sredi zhenshchin $\mathrm{v}$ Respublike Dagestan. Available: https://cyberleninka.ru/article/n/problemyekstremizma-sredi-zhenschin-v-respublikedagestan. (Accessed: 10.03.2018).
7. (2018) Poryadka 500 grazhdan Kyrgyzstana nahodyatsya v Sirii v ryadah IG - Genprokuror I. Dzholdubaeva Available: http://old.kabar.kg/rus/law-andorder/full/98746. (Accessed: 10.03.2018).

8. (2018) Odna iz prichin religioznoj radikalizacii molodezhi - social'naya nespravedlivost'. Available: https://24.kg/obschestvo/75314_odna izprichin _religioznoy_radikalizatsii_molodeji_sotsialnay a nespravedlivost/. (Accessed: 10.03.2018).

9. Alimova K.T. (2016) Religioznyj ehkstremizm v Kyrgyzstane $\mathrm{v}$ perekhodnyj period // Aktual'nye voprosy obshchestvennyh nauk: sociologiya, politologiya, filosofiya, istoriya: sb. st. po mater. LVII mezhdunar. nauch.-prakt. konf. № 1(53). - Novosibirsk: SibAK, 2016.

10. (2017) Religioznyj ehkstremizm v stranah Central'noj Azii. Available: https://ru.sputnik.kg/infographics/20171213/10 36820007/o-religioznom-ehkstremizme-vcentralnoj-azii.html (Accessed: 10.03.2018). 